\title{
Three new lichen species from Macaronesia belonging in Ramalinaceae, with the description of a new genus
}

\author{
Pieter P. G. van den Boom ${ }^{1,2^{\star}}$ \& Nicolas Magain ${ }^{2}$
}

\section{Article info}

Received: 30 Sept. 2019

Revision received: 6 Mar. 2020

Accepted: 11 Mar. 2020

Published: 2 Jun. 2020

Associate Editor

Bernard Goffinet

\begin{abstract}
Tylocliostomum is described as a new genus and T. viridifarinosum as a new species. Two Bacidina species, B. pallidocarpa and B. violacea, are also described as new to science. They all occur in Macaronesia (Azores, Madeira).
\end{abstract}

Key words: Ascomycota, Lecanorales, Tylothallia, type species, molecular phylogenetics

\section{Introduction}

An extensive study of lichens and lichenicolous fungi in the Azores and Madeira by the first author resulted in several works already published from Sao Miguel and Terceira (van den Boom 2015b, 2016; Guzow-Krzemińska et al. 2019) and from Madeira (van den Boom 2015a, b; van den Boom \& Ertz 2014). Several Bacidia or Bacidina species are recorded in van den Boom (2015a) and van den Boom \& Alvarado (2019). Ten species of these genera are recorded in the checklist of Madeira, including the endemic species Bacidia albonigrans, B. endoleucoides and $B$. fritzei (Carvalho et al. 2008). Fifteen species of these genera are recorded in the checklist of the Azores, with none of them being endemic (Aptroot et al. 2010).

In this study we describe two new Bacidina species: $B$. violacea, known from the Azores and Madeira, and B. pallidocarpa, endemic to the Azores. Tylocliostomum is described as a new genus and T. viridifarinosum as a new species, known only from the type locality in Madeira.

\section{Materials and methods}

Material acquisition

This study is mainly based on extensive collections of Bacidia s.l. made by the first author on several Macaronesian islands in 2017 and 2019 and hosted in LG and the private herbarium of the first author. Hand-cut apothecial sections and squashed thallus preparations were examined with a compound microscope (Olympus BX2).

\footnotetext{
${ }^{1}$ Arafura 16, 5691JA, Son, The Netherlands

2 Evolution and Conservation Biology, InBios Research Center, Institut de Botanique B22, Université de Liège, Chemin de la vallée 4, 4000 Liège, Belgium

* Corresponding author e-mail: pvdboom@kpnmail.nl
}

Ascospores and other anatomical details were studied and measured in water or in $10 \%$ potassium hydroxide $(\mathrm{K})$ if features were otherwise unseparated. In each collection ( $\sim 5$ well-developed ascospores representing the observed variation of size and shape), conidia and paraphyses were measured to $0.1 \mu \mathrm{m}$ accuracy.

Chemical spot tests were performed under a compound microscope using sodium hypochlorite (C) and K (Orange et al. 2001). Pigments were determined following the system of Meyer \& Printzen (2000). The crystals from all studied specimens were investigated in tissue sections by using a compound microscope with polarization filters. For a detailed comparison of the main diagnostic features of the two new Bacidina species and the most similar Bacidina species, see Table 1.

\section{Molecular data}

DNA was extracted from two specimens of Bacidina pallidocarpa and two specimens of $B$. violacea, and two DNA extractions were performed from the same material of Tylocliostomum viridifarinosum (Table S1). Extraction of DNA followed the protocol of Cubero et al. (1999). We sequenced the ribosomal nuclear loci ITS using primers ITS1F (Gardes \& Bruns 1993) and ITS4 (White et al. 1990), the mitochondrial ribosomal locus mtSSU with primers SSU1 and SSU3R (Zoller et al. 1999), and part of the protein-coding gene RPB1 with RPB1AF (Stiller \& Hall 1997) and VH6R (Hofstetter et al. 2007).

For the three loci, PCR conditions were as follows: initial denaturation at $95^{\circ} \mathrm{C}$ for $1 \mathrm{~min}$, followed by 35 cycles of denaturation at $95^{\circ} \mathrm{C}$ for $45 \mathrm{sec}$, a different annealing phase for each locus, then an elongation phase of $1 \mathrm{~min}$ at $72^{\circ} \mathrm{C}$, followed by a final elongation phase of $10 \mathrm{~min}$ at 
Table 1. Main diagnostic features of Bacidina species similar to B. pallidocarpa and B. violacea.

\begin{tabular}{|c|c|c|c|c|c|c|c|}
\hline Species & Thallus & Colour & Apothecia & Margin & Disc & Ascospores & Pycnidia \\
\hline B. pallidocarpa & $\begin{array}{l}\text { smooth to fine } \\
\text { warted, granular } \\
\text { to fine isidiate }\end{array}$ & $\begin{array}{l}\text { greenish with } \\
\pm \text { pale brown } \\
\text { tinge }\end{array}$ & $\begin{array}{l}0.15- \\
0.55 \mathrm{~mm}\end{array}$ & $\begin{array}{l}\text { somewhat paler than } \\
\text { disc, soon becoming } \\
\text { immarginate }\end{array}$ & $\begin{array}{l}\text { white to pale } \\
\text { cream with } \\
\text { yellowish tinge }\end{array}$ & $\begin{array}{l}25-38 \\
\times 1-1.2 \mu \mathrm{m}\end{array}$ & $\begin{array}{l}\text { white, } \\
\text { one type }\end{array}$ \\
\hline B. violacea & areolate, farinose & $\begin{array}{l}\text { yellowish } \\
\text { brown to very } \\
\text { pale brown }\end{array}$ & $0.2-0.7 \mathrm{~mm}$ & $\begin{array}{l}\text { paler than disc, with } \\
\text { violet tinge }\end{array}$ & dark brown & $\begin{array}{l}25-50 \\
\times 1-1.5 \mu \mathrm{m}\end{array}$ & unknown \\
\hline B. adastra & $\begin{array}{l}\text { sorediate to } \\
\text { thickly leprose }\end{array}$ & green & $0.4-0.7 \mathrm{~mm}$ & $\begin{array}{l}\text { concolorous with } \\
\text { or slightly paler } \\
\text { than disc }\end{array}$ & $\begin{array}{l}\text { pale pink to } \\
\text { dark blue-black }\end{array}$ & $\begin{array}{l}40-50 \\
\times 0.9-1.2 \mu \mathrm{m}\end{array}$ & $\begin{array}{l}\text { white, } \\
\text { one type }\end{array}$ \\
\hline B. brittoniana & $\begin{array}{l}\text { rimose to areolate, } \\
\text { areoles convex }\end{array}$ & $\begin{array}{l}\text { pale grey to } \\
\text { grey-green }\end{array}$ & $0.2-0.4 \mathrm{~mm}$ & $\begin{array}{l}\text { concolorous with } \\
\text { or slightly paler } \\
\text { than disc, finally } \\
\text { excluded }\end{array}$ & $\begin{array}{l}\text { pale pink to } \\
\text { purple-brown }\end{array}$ & $\begin{array}{l}23-41 \\
\times 1.7-2.4 \mu \mathrm{m}\end{array}$ & $\begin{array}{l}\text { concolorous } \\
\text { with } \\
\text { apothecia, } \\
\text { one type }\end{array}$ \\
\hline B. californica & $\begin{array}{l}\text { wrinkled or } \\
\text { warted, } \pm \text { rimose, } \\
\text { or granular } \\
\text { areolate }\end{array}$ & $\begin{array}{l}\text { pale pink to } \\
\text { orange brown }\end{array}$ & $0.4-0.7 \mathrm{~mm}$ & $\begin{array}{l}\text { concolorous with or } \\
\text { paler or darker than } \\
\text { disc }\end{array}$ & $\begin{array}{l}\text { pale pink to } \\
\text { purple-brown to } \\
\text { blackish }\end{array}$ & $\begin{array}{l}31-53 \\
\times 1.9-3.3 \mu \mathrm{m}\end{array}$ & $\begin{array}{l}70-100 \mu \mathrm{m}, \\
\text { two types }\end{array}$ \\
\hline B. chloroticula & scurfy granular & $\begin{array}{l}\text { dull or grey- } \\
\text { green to pale } \\
\text { brownish }\end{array}$ & $0.1-0.2 \mathrm{~mm}$ & paler than disc & $\begin{array}{l}\text { whitish or } \\
\text { pink-orange to } \\
\text { pale grey-brown }\end{array}$ & $\begin{array}{l}20-38 \\
\times 1-1.8 \mu \mathrm{m}\end{array}$ & $\begin{array}{l}\text { white, } \\
\text { one type }\end{array}$ \\
\hline B. contexta & $\begin{array}{l}\text { rugulose to } \\
\text { microsquamulose }\end{array}$ & $\begin{array}{l}\text { olivaceous } \\
\text { green }\end{array}$ & $\begin{array}{l}0.2- \\
0.45 \mathrm{~mm}\end{array}$ & $\begin{array}{l}\text { concolorous with } \\
\text { disc }\end{array}$ & $\begin{array}{l}\text { pale beige, } \\
\text { waxy white or } \\
\text { pale pinkish } \\
\text { orange }\end{array}$ & $\begin{array}{l}32-41 \\
\times 1.2-1.6 \mu \mathrm{m}\end{array}$ & unknown \\
\hline B. delicata & fine granular & $\begin{array}{l}\text { pale green to } \\
\text { fawn }\end{array}$ & $0.3-0.6 \mathrm{~mm}$ & paler than disc & $\begin{array}{l}\text { white, beige or } \\
\text { orange-pink }\end{array}$ & $\begin{array}{l}24-48 \\
\times 1-1.5 \mu \mathrm{m}\end{array}$ & $\begin{array}{l}\text { white, } \\
\text { one type }\end{array}$ \\
\hline B. egenuloidea & fine granular & grey-green & $0.3-0.4 \mathrm{~mm}$ & $\begin{array}{l}\text { concolorous with or } \\
\text { darker than disc }\end{array}$ & $\begin{array}{l}\text { pale orange to } \\
\text { dark purple- } \\
\text { brown }\end{array}$ & $\begin{array}{l}25-34 \\
\times 1.1-1.9 \mu \mathrm{m}\end{array}$ & $\begin{array}{l}\text { hyaline, } \\
75-200 \mu \mathrm{m}, \\
\text { three types }\end{array}$ \\
\hline B. inundata & $\begin{array}{l}\text { granular warted, } \\
\text { cracked }\end{array}$ & $\begin{array}{l}\text { grey-green to } \\
\text { green-fawn }\end{array}$ & $0.2-0.6 \mathrm{~mm}$ & $\begin{array}{l}\text { paler than disc, } \\
\text { often becoming } \\
\text { excluded }\end{array}$ & $\begin{array}{l}\text { pale to dark } \\
\text { brown }\end{array}$ & $\begin{array}{l}24-43 \\
\times 2-2.5 \mu \mathrm{m}\end{array}$ & $\begin{array}{l}\text { white or dark } \\
\text { brown, } \\
\text { two types }\end{array}$ \\
\hline B. mendax & $\begin{array}{l}\text { scurfy, uneven } \\
\text { crust or small } \\
\text { warts }\end{array}$ & $\begin{array}{l}\text { straw-coloured } \\
\text { to bright green }\end{array}$ & $0.2-0.7 \mathrm{~mm}$ & $\begin{array}{l}\text { concolorous with } \\
\text { or paler than disc, } \\
\pm \text { finally excluded }\end{array}$ & $\begin{array}{l}\text { from whitish to } \\
\text { fuscous-brown }\end{array}$ & $\begin{array}{l}30-38 \\
\times 1.2-1.5 \mu \mathrm{m}\end{array}$ & $\begin{array}{l}\text { pale, } \\
150-300 \mu \mathrm{m}, \\
\text { one type }\end{array}$ \\
\hline B. neosquamulosa & squamulose & $\begin{array}{l}\text { green-grey } \\
\text { to olive }\end{array}$ & $0.2-1 \mathrm{~mm}$ & $\begin{array}{l}\text { grey to dark brown, } \\
\text { persistent }\end{array}$ & $\begin{array}{l}\text { pink-buff to } \\
\text { flesh-coloured } \\
\text { with blackened } \\
\text { areas }\end{array}$ & $\begin{array}{l}40-55 \\
\times 1.3-1.7 \mu \mathrm{m}\end{array}$ & $\begin{array}{l}\text { colourless to } \\
\text { olive-grey, } \\
70-130 \mu \mathrm{m}, \\
\text { abundant, one } \\
\text { type }\end{array}$ \\
\hline B. phacodes & warted to scurfy & $\begin{array}{l}\text { white } \\
\text { to grey-green }\end{array}$ & $0.2-0.5 \mathrm{~mm}$ & paler than disc & $\begin{array}{l}\text { white, beige } \\
\text { or pale } \\
\text { orange-pink }\end{array}$ & $\begin{array}{l}29-45 \\
\times 1.5-2 \mu \mathrm{m}\end{array}$ & $\begin{array}{l}\text { hyaline, } \\
\text { one type }\end{array}$ \\
\hline B. pseudoisidiata & $\begin{array}{l}\text { filmy thin, } \\
\text { fine granular to } \\
\text { coralloid }\end{array}$ & $\begin{array}{l}\text { dull greenish to } \\
\text { grayish green }\end{array}$ & $0.2-0.4 \mathrm{~mm}$ & $\begin{array}{l}\text { thinly marginate, } \\
\text { becoming } \\
\text { immarginate }\end{array}$ & $\begin{array}{l}\text { pale yellowish } \\
\text { to yellowish } \\
\text { orange }\end{array}$ & $\begin{array}{l}25-35 \\
\times 1.1-1.8 \mu \mathrm{m}\end{array}$ & $\begin{array}{l}\sim 50 \mu \mathrm{m}, \\
\text { hyaline to pale } \\
\text { brownish, one } \\
\text { type }\end{array}$ \\
\hline B. ramea & $\begin{array}{l}\text { wrinkled or } \\
\text { warted to areolate }\end{array}$ & $\begin{array}{l}\text { pale grey, pale } \\
\text { yellow-grey or } \\
\text { pale green-gray }\end{array}$ & $0.4-0.6 \mathrm{~mm}$ & thin, thalline & $\begin{array}{l}\text { pale yellow, } \\
\text { pale pink to } \\
\text { orange brown }\end{array}$ & $\begin{array}{l}31-49 \\
\times 1.6-2.2 \mu \mathrm{m}\end{array}$ & $\begin{array}{l}\text { hyaline, } \\
\sim 100 \mu \mathrm{m}, \\
\text { one type }\end{array}$ \\
\hline B. squamellosa & $\begin{array}{l}\text { flat, deeply incised } \\
\text { squamules, lobes } \\
20-30 \mu \mathrm{m} \text { wide }\end{array}$ & pink & $0.3-0.5 \mathrm{~mm}$ & $\begin{array}{l}\text { concolorous } \\
\text { with disc, finally } \\
\text { excluded }\end{array}$ & pale pink & $\begin{array}{l}45-48 \\
\times 1.3-1.4 \mu \mathrm{m}\end{array}$ & $\begin{array}{l}\text { hyaline, } \\
75-100 \mu \mathrm{m}, \\
\text { three types }\end{array}$ \\
\hline B. sulphurella & finely granular & $\begin{array}{l}\text { dull yellow- } \\
\text { green to fawn }\end{array}$ & $0.3-0.7 \mathrm{~mm}$ & $\begin{array}{l}\text { paler than disc, } \\
\text { white-pruinose }\end{array}$ & $\begin{array}{l}\text { white gray to } \\
\text { grey-brown }\end{array}$ & $\begin{array}{l}24-46 \\
\times 1-2 \mu \mathrm{m}\end{array}$ & $\begin{array}{l}\text { white, } \\
\text { one type }\end{array}$ \\
\hline
\end{tabular}

$72^{\circ} \mathrm{C}$. For ITS the annealing phase was $52^{\circ} \mathrm{C}$ for $45 \mathrm{sec}$; for RPB1, $1 \mathrm{~min}$ at $56^{\circ} \mathrm{C}$; and for $\mathrm{mtSSU}, 1 \mathrm{~min}$ at $58^{\circ} \mathrm{C}$. PCR fragments were purified using EXO-SAP (VWR International, West Chester, PA, USA) and sequenced by Macrogen Europe (Amsterdam, The Netherlands). Sequence fragments were assembled using Geneious v. 10.2.3 (Biomatters LTD). Matrices were assembled in Mesquite v. 3.11 (Maddison \& Maddison 2016), aligned using MAFFT v. 7.305b with default parameters (Katoh $\&$ Standley 2013) and further inspected by eye. Ambiguous regions were delimited manually and excluded from the analyses.

\section{Phylogenetic analyses}

We downloaded ITS, mtSSU and RPB1 alignments from Kistenich et al. (2018). We pruned them to keep 
a maximum of two representatives per genus, following the new classification from Kistenich et al. (2018), and favouring type species, then taxa with all or most of the three loci, except in clades where sequences exhibited high similarity with our sequences, where all representatives were kept. Catillaria contristans, Catillaria erysiboides, Glyphopeltis ligustica, Protoblastenia rupestris and Psora decipiens were selected as outgroups and other outgroup taxa were further removed (Table S1). We further selected additional sequences showing high similarity to our collections by performing BLASTn searches in the GenBank nucleotide collection (Wheeler et al. 2007), and added them to our dataset. In particular, numerous sequences from Switzerland (Mark et al. 2016) and Central and Eastern Europe (Czarnota \& Guzow-Krzemińska 2012, 2018) were added. Single-locus matrices consisted of 100 sequences for ITS, 71 sequences for mtSSU, and 57 sequences for RPB1. The best ML tree was inferred for each locus using RAxML v. 8.2.9 (Stamatakis 2006), searching for the best ML tree and performing 1000 bootstrap pseudoreplicates in the same run, with the GTRGAMMA model and default parameters. Congruence was examined by eye and no significant conflict between loci was observed. The data were therefore concatenated using the combine.pl script from the PLexus package (Magain 2018). The data were partitioned in 7 subsets as follows: ITS1, 5.8S, ITS2, mtSSU, and the three codon positions of RPB1. The best partitioning scheme was inferred using PartitionFinder2 (Lanfear et al. 2016) on the CIPRES portal (Miller et al. 2010) using the BIC criterion and the greedy algorithm.

The three-locus concatenated alignment consisted of 115 taxa and 1850 characters. For the three-locus matrix, the best likelihood tree was inferred with RAxML v. 8.2.12 (Stamatakis 2006; Stamatakis et al. 2008) as implemented on the CIPRES portal with the default settings and the GTRGAMMA model, and bootstrapped in the same run, letting RAxML automatically stop the bootstrap, and using the best partition obtained with PartitionFinder. We further ran, for the same matrix, a Bayesian analysis using MrBayes v. 3.2.6 (Huelsenbeck \& Ronquist 2001) on the CIPRES portal using the partition and the substitution models determined by PartitionFinder, running for 20 million generations and sampling every $1000^{\text {th }}$ generation. The analysis consisted of two runs of three heated chains and one cold one. We assessed the convergence using Tracer v. 1.6 (Rambaut \& Drummond 2007). The first 25\% of trees were discarded as burn-in. Branches of the phylogenetic trees were considered strongly supported if bootstrap support was higher than 70 for maximum likelihood analyses and posterior probabilities higher than 0.95 for the Bayesian analysis.

\section{Results and discussion}

Molecular data

We obtained 3 ITS, 3 mtSSU and 4 RPB1 sequences. We obtained ITS and RPB1 sequences from one specimen of Bacidina violacea, whereas we could not obtain any sequences from the other specimen. We obtained mtSSU and RPB1 sequences from one B. pallidocarpa specimen, and only mtSSU for the other specimen. We obtained ITS and RPB1 sequences from the two DNA extractions of Tylocliostomum viridifarinosum (Table S1).

\section{Phylogenetic analyses}

The final 3-locus alignment consisted of 131 taxa and 1872 characters. The best partitioning scheme retrieved by PartitionFinder consists of a single set. The best substitution model recovered was GTR $+\mathrm{I}+\mathrm{G}$. Our best ML tree retrieves the monophyletic family Ramalinaceae as circumscribed by Kistenich et al. (2018), with high support $[\mathrm{ML}$ Bootstrap $(\mathrm{BS})=75$, Bayesian posterior probabilities $(p p)=1$; Fig. 4]. In both the ML and the Bayesian analyses, we recovered clades $\mathrm{D}(\mathrm{BS}=72$, $\mathrm{pp}=1), \mathrm{E}(\mathrm{BS}=100, \mathrm{pp}=1)$ and $\mathrm{G}(\mathrm{BS}=85, \mathrm{pp}=1)$ sensu Kistenich et al. (2018) as monophyletic with high support, clade $\mathrm{F}(\mathrm{BS}=77, \mathrm{pp}=0.77)$ with high support in the ML analysis only, and clade $\mathrm{C}(\mathrm{BS}=65, \mathrm{pp}=0.90)$ as monophyletic without support. We recovered the same sister relationships of clades $\mathrm{C}$ and $\mathrm{D}$ without support $(\mathrm{BS}=49, \mathrm{pp}=0.84)$ in the ML analysis, and clades $\mathrm{C}, \mathrm{D}$ and $\mathrm{E}$ formed a well-supported group $(\mathrm{BS}=79, \mathrm{pp}=1)$ in the Bayesian analysis. We did not recover a sister relationship between clades F and G. Instead, we recovered clade $\mathrm{F}$ as sister to clades $\mathrm{C}, \mathrm{D}$ and $\mathrm{E}$, highly supported in the Bayesian analysis $(\mathrm{BS}=69, \mathrm{pp}=1)$.

The genus Bacidina appears paraphyletic in our analyses, as it appeared in Kistenich et al. (2018). Bacidina pallidocarpa and B. violacea belong to a well-supported clade corresponding to part of the genus Bacidina, labelled Bacidina clade II (Fig. 4, BS =98, pp =1) within clade D. The type species of the genus, $B$. phacodes, belongs to the other clade, labelled Bacidina clade I in Figure 4. Within Bacidina clade II, B. violacea is part of a highly supported group resulting from the first split within the genus $(\mathrm{BS}=98, \mathrm{pp}=1)$, along with four accessions from Switzerland labelled Bacidina arnoldiana aggr. (Mark et al. 2016). However, the true Bacidina arnoldiana, including a representative from Kistenich et al. (2018) and one from the AFTOL fungal tree of life, belongs to another clade within Bacidina. The four accessions from Switzerland may belong to $B$. violacea but the morphology of these specimens could not be examined. Bacidina pallidocarpa appears as sister species of B. neosquamulosa (represented by two accessions from the Netherlands) with high support in the $\mathrm{ML}$ analysis $(\mathrm{BS}=88, \mathrm{pp}=0.85)$. If the genus Bacidina was to be split in two, the names Woessia (type species corresponding to B. sulphurella) and Lichingoldia (type species corresponding to B. inundata) could accommodate Bacidina clade II, containing B. pallidocarpa and B. violacea.

Tylocliostomum viridifarinosum belongs to clade $\mathrm{G}$, and more specifically forms a well-supported group with Tylothallia biformigera and two accessions of Cliostomum haematommatis $(\mathrm{BS}=0.99, \mathrm{pp}=1)$. Cliostomum haematommatis accomodates the pycnidiate state of a species initially described as Lichenophoma haematommatis (Hawksworth et al. 2006). However, these two 
accessions likely do not represent the genus Cliostomum sensu stricto, as Cliostomum corrugatum, the type species of the genus, belongs to a different subclade within clade $\mathrm{G}$.

\section{Taxonomic treatment}

Bacidina pallidocarpa van den Boom \& Magain, sp. nov.

(Fig. 1A-B)

\section{MycoBank MB 834077}

Diagnosis: A Bacidina species similar to B. chloroticula in habitus but differing in all the following characters: continuous granular to finely isidiate thallus, slightly shiny, thinly marginate to soon emarginate, larger $(0.15-0.55 \mathrm{~mm}$ diam.) apothecia, white to slightly pale cream, plane to convex, disc, acicular, 1-3-septate, $25-38 \times 1-1.2(-1.5) \mu \mathrm{m}$ ascospores, rare, $50-150 \mu \mathrm{m}$ diam. pycnidia, and 20-35 × 0.8-1 $\mu \mathrm{m}, 0-3$-septate conidia.

Type: Portugal, Azores, São Jorge, E of Santo Amaro, Reserva Florestal das Macelas, small open forest with mixed trees and shrubs, including Metrosideros trees and Camellia shrubs, on wood of fence post, $38^{\circ} 40.61^{\prime} \mathrm{N}, 28^{\circ} 09.78^{\prime} \mathrm{W}, 450 \mathrm{~m}$, 4 September 2017, P. \& B. van den Boom 57031 (LG - holotype; LISU, herb. van den Boom - isotypes).

Description. Thallus corticolous, thin, continuous, smooth to fine warted, granular to fine isidiate, greenish, sometimes with pale brown tinge, slightly shiny, 50-100 $\mu \mathrm{m}$ high, without crystals. Prothallus not present. Photobiont chlorococcoid, cells 4-12 $\mu \mathrm{m}$ diam. Apothecia abundantly present, scattered, $0.15-0.55 \mathrm{~mm}$ diam., sometimes thinly marginate when young, margin somewhat paler than disc, 20-40 $\mu \mathrm{m}$ wide, soon becoming immarginate; disc plane to weakly convex, white or pale cream, or with yellowish tinge. Excipulum hyaline, without crystals, laterally with paraplectenchymatous cells, up to $8 \mu \mathrm{m}$ diam. and below with radiating cells, cells conglutinated, lumina 5-8 $\times 2-3.5 \mu \mathrm{m}$, with rather thick walls ( $2-3 \mu \mathrm{m}$ between adjacent cell lumina). Epithecium hyaline or very pale yellowish brown, without crystals, $\mathrm{K}-, \mathrm{N}-$. Hymenium $25-45 \mu \mathrm{m}$ high, without any pigment. Hypothecium hyaline, 25-40 $\mu \mathrm{m}$ high, $\mathrm{K}-$. Hamathecium of paraphyses simple, thin, $1-1.5 \mu \mathrm{m}$ wide, septate, tips slightly to strongly widened, up to $5 \mu \mathrm{m}$, not pigmented. Asci abundant, Bacidia-type, small, cylindrical to slightly clavate, $25-40 \times 7-10 \mu \mathrm{m}, 8$-spored, tholus rather thin, weakly amyloid, more strongly amyloid below and at apex, ocular chamber lacking. Ascospores acicular, clearly coiled in ascus, varying from straight to slightly sigmoid, 1-3-septate, 25-38 × 1-1.2(-1.5) $\mu \mathrm{m}$. Pycnidia rare, inconspicuous, immersed in thallus, 50-150 $\mu \mathrm{m}$ diam., white. Conidia filiform, straight to strongly curved, 20-35 $\times 0.8-1 \mu \mathrm{m}, 0-3$-septate.

Chemistry. $\mathrm{K}-, \mathrm{C}-, \mathrm{P}-, \mathrm{UV}-$, no chemical compounds detected.

Etymology. The epithet refers to the habitus of the apothecia, especially the always white to pale cream colour.

Distribution and ecology. Azores, known from four localities, where it grows always abundantly, on trunks of trees and on wood of fences. At the type locality no
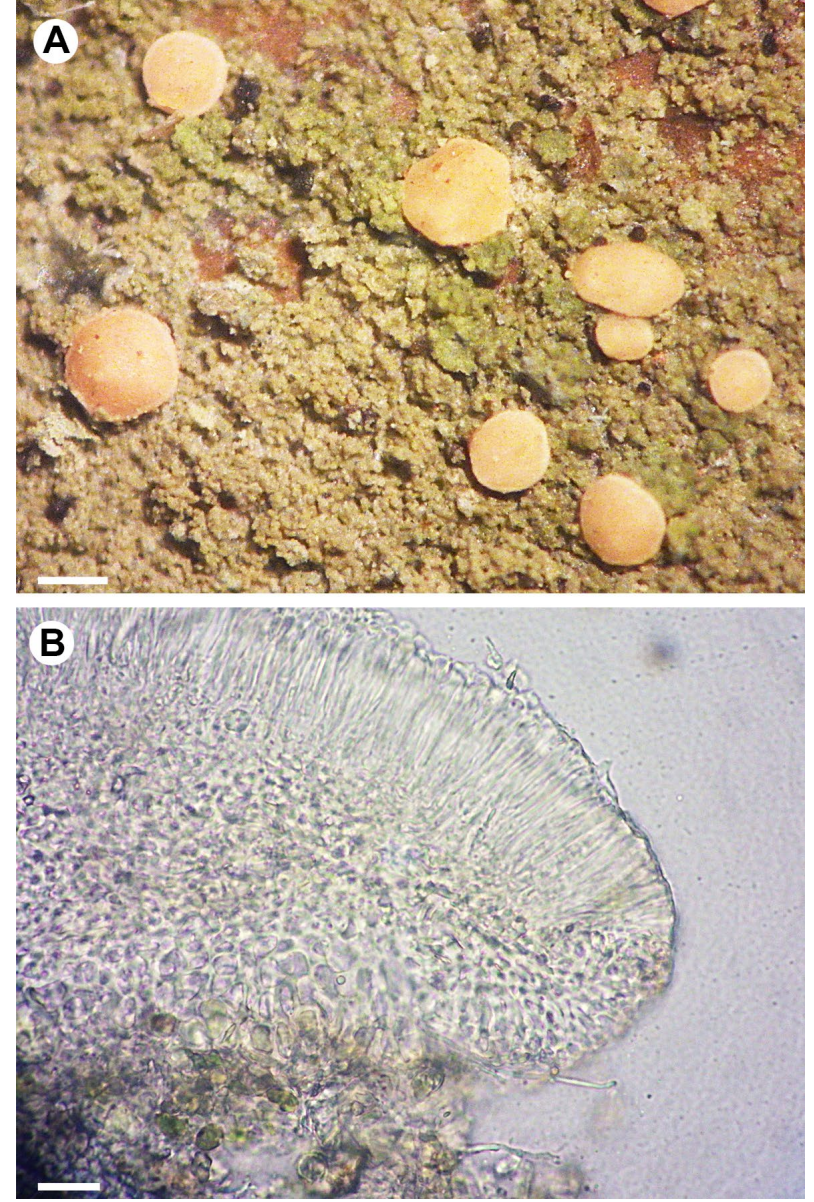

Figure 1. Bacidina pallidocarpa (holotype). A-habitus; B - excipulum Scales: $\mathrm{A}=0.3 \mathrm{~mm} ; \mathrm{B}=20 \mu \mathrm{m}$.

additional lichens have been found, not even in the collection (56937) from Pico.

Notes. The most similar species, Bacidina chloroticula, for which it can be mistaken in the field, differs by the whitish, pale pinkish, yellowish, or pale grey-brown apothecia, the scurfy greenish to pale brownish thallus, \pm cracked to areolate, its much smaller apothecia, up to $0.2 \mathrm{~mm}$ diam, and ascospores somewhat wider $(1-1.8 \mu \mathrm{m})$, 0-3-septate. For further main diagnostic features of similar Bacidina species, see Table 1.

The new species somewhat resembles Bacidia assulata s.l. because the apothecia are pale brick-red to very pale orange-brown, but the ascospores are much longer and $1.5-2 \mu \mathrm{m}$ wide.

In the field it is easily confused with Lecania chlorotiza, but that species has smaller apothecia $(0.1-0.3 \mathrm{~mm}$ diam.) and 0-1-septate ascospores.

Additional specimens examined. PORTUGAL. Azores, São Jorge, NW of Velas, WNW of Rosais, trail to Farol dos Rosais, near Chã do Areeiro, small forest with Erica and Pittosporum and stones of walls, on trunk of unidentified tree, $38^{\circ} 44.82^{\prime} \mathrm{N}, 28^{\circ} 17.92^{\prime} \mathrm{W}$, 290 m, 7 September 2017, P. \& B. van den Boom 57177 (herb. van den Boom); Pico, E of Madalena, Parque Florestal da Quinta das Rosas, botanical garden with mixed shrubs and trees, including some exotic trees, on trunk of ginkgo, $38^{\circ} 31.38^{\prime} \mathrm{N}, 28^{\circ} 29.38^{\prime} \mathrm{W}$, 150 m, 29 August 2017, P. \& B. van den Boom 56556 (herb. van den Boom); 2 km W of São João, Reserva Florestal São João, 
S side of road ER1, picnic area with small Pinus Pittosporum forest, on wood of fence, $38^{\circ} 25.06^{\prime} \mathrm{N}, 28^{\circ} 21.72^{\prime} \mathrm{W}, 85 \mathrm{~m}$, 2 September 2017, P. \& B. van den Boom 56937 (herb. van den Boom).

Bacidina violacea van den Boom \& Magain, sp. nov.

(Fig. 2A-B)

MycoBank MB 834078

Diagnosis: A Bacidina species similar to B. caligans in habitus but differing in all the following characters: completely farinose thallus, greyish brown (with violet tinge), paler than the disc, apothecial margin, dark brown disc, brown-pigmented epithecium, brown hypothecium, acicular, straight to slightly curved, 1-5-septate, $(25-) 35-50 \times 1-1.5 \mu \mathrm{m}$ ascospores.

Type: Portugal, Azores, Pico, W side of island, E of Madalena, Parque Florestal da Quinta das Rosas, botanical garden with mixed shrubs and trees, including some exotic trees, $38^{\circ} 31.38^{\prime} \mathrm{N}$, $28^{\circ} 29.38^{\prime} \mathrm{W}, 150 \mathrm{~m}, 29$ August 2017, P. \& B. van den Boom 56552 (LG - holotype; LISU, herb. van den Boom - isotypes).

Description. Thallus corticolous, areolate, farinose, yellowish brown to very pale brown, matte, $50-100 \mu \mathrm{m}$ high, granules (goniocysts) 20-50 $\mu \mathrm{m}$ diam., without crystals. Prothallus not present. Photobiont chlorococcoid, cells 5-12 $\mu \mathrm{m}$ diam. Apothecia abundantly present, scattered, $0.2-0.7 \mathrm{~mm}$ diam., thinly marginate, especially when young, margin paler than disc, greyish brown with dark violet tinge, becoming immarginate, $30-50 \mu \mathrm{m}$ wide; disc plane to weakly convex, dark brown. Excipulum
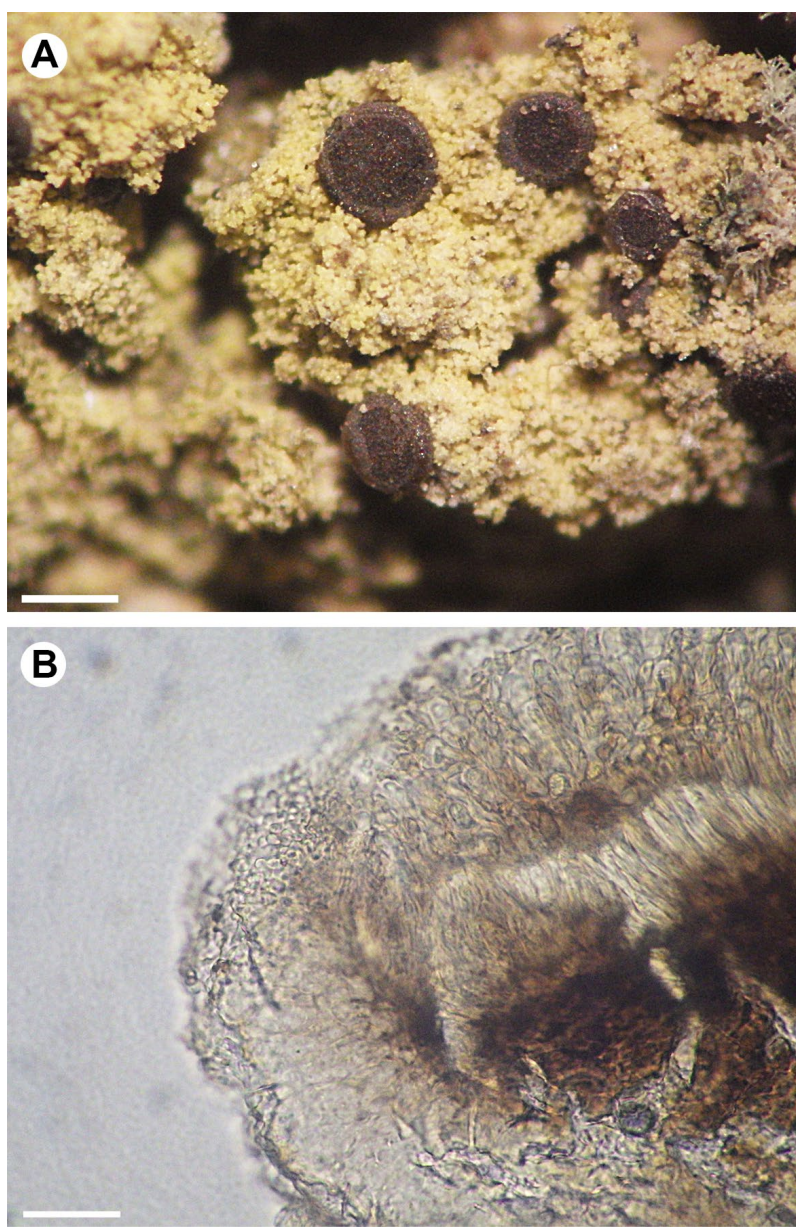

Figure 2. Bacidina violacea (holotype). A - habitus; B - excipulum. Scales: $\mathrm{A}=0.5 \mathrm{~mm} ; \mathrm{B}=30 \mu \mathrm{m}$.
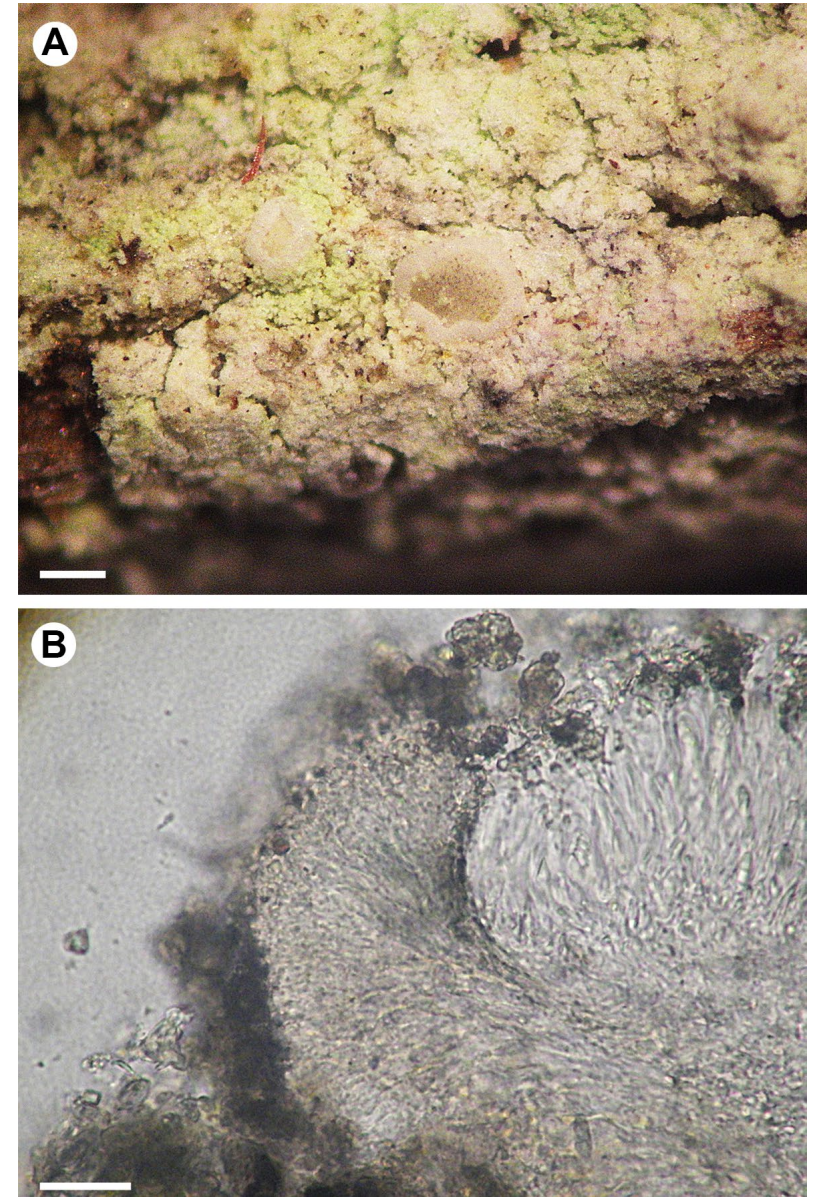

Figure 3. Tylocliostomum viridifarinosum (holotype). A - habitus; $\mathrm{B}$ - excipulum. Scales: $\mathrm{A}=0.2 \mathrm{~mm} ; \mathrm{B}=20 \mu \mathrm{m}$.

partly reddish brown, without crystals, laterally with small paraplectenchymatous cells, up to $4 \mu \mathrm{m}$ diam., and below with radiating cells, cells strongly conglutinated, isodiametric, lumina 2-3.5 $\mu \mathrm{m}$ wide, with rather thick walls (2-3 $\mu \mathrm{m}$ between adjacent cell lumina). Epithecium very pale yellowish brown, without crystals, $\mathrm{K}-, \mathrm{N}-$. Hymenium $45-55 \mu \mathrm{m}$ high, without any pigment. Hypothecium brown, up to $75 \mu \mathrm{m}$ high, $\mathrm{K}-$. Hamathecium of paraphyses thin, 1.2-2 $\mu \mathrm{m}$ wide, septate, tips often slightly to more clearly widened, up to $3.5 \mu \mathrm{m}$, often slightly brownish-pigmented. Asci abundant, Bacidia-type, small, cylindrical to slightly clavate, $35-45 \times 9-11 \mu \mathrm{m}, 8$-spored, tholus rather thick, weakly amyloid, more strongly amyloid below and at apex, ocular chamber lacking. Ascospores acicular, straight in ascus, sigmoid, 1-5-septate, (25-)35-50 × 1-1.5 $\mu \mathrm{m}$. Pycnidia not detected.

Chemistry. K-, C-, P-, UV-, no chemical compounds detected. No crystals detected in apothecia or thallus. Superba-brown (Meyer \& Printzen 2000) present in apothecia.

Etymology. The epithet refers to the colour of the apothecial margin.

Distribution and ecology. Azores and Madeira, known from two localities only, where it grows abundantly, on trunks of an unidentified tree (type locality) and branches of a Michelia doltsopa tree. No accompanying lichen species have been found. 


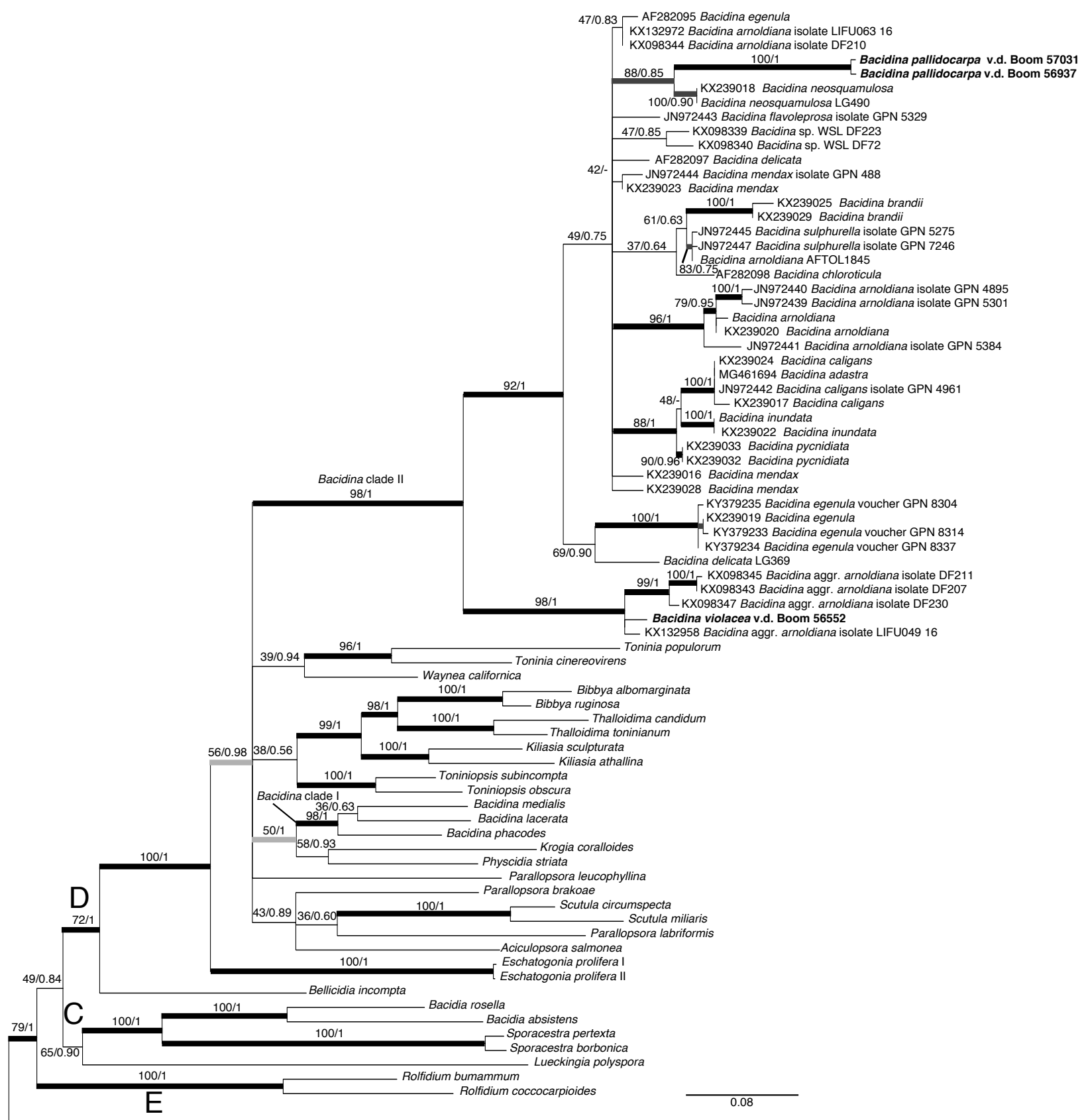

Figure 4. Best ML phylogenetic tree of the Ramalinaceae, based on the 3-locus matrix (ITS, mtSSU, RPB1). Branches with ML bootstrap values less than 30 were collapsed using TreeGraph2 (Stover and Muller 2010). Rooting, delimitation of Ramalinaceae and capital letters representing clades (C-G) follow Kistenich et al. (2018). ML bootstrap support values (BS) and Bayesian posterior probabilities (pp) are indicated above or below the branches, before and after the slash, respectively. Thick black branches have BS $\geq 70$ and $\mathrm{pp} \geq 0.95$. Thick dark grey branches have $\mathrm{BS} \geq 70$ but $\mathrm{pp}<0.95$, whereas thick light grey branches have $\mathrm{pp} \geq 0.95$ but BS $<70$. The two Bacidina clades are indicated on the tree. Newly described species are bolded.

Notes. It is most likely to be confused in the field with Bacidina caligans, but that species has a scurfy granular-sorediate thallus, the granules are somewhat wider $(20-50 \mu \mathrm{m})$, the margin of the apothecia is darker than the disc, and it has white to pink immersed pycnidia. Pycnidia are unknown in the new species. A similar species, Bacidina sulphurella, for which it also can be mistaken in the field, differs by the mainly grey brown apothecia which have a raised margin and are often white pruinose; the excipulum has ellipsoid lumina $\sim 3-7 \times 1.5-5 \mu \mathrm{m}$ and the ascospores are 1-3-septate.
A Bacidia species described from Macaronesia (El Hierro), B. subilludens, also has a brown hypothecium but the apothecia are black and the pycnidia are abundant, with conidia 5-8 $\times 1 \mu \mathrm{m}$ (Pitard \& Harmand 1911).

The thallus of Bacidina delicata is rather similar to that of the new species but has white to orange-pink apothecia and a hyaline hypothecium. Bacidia arceutina often has dark brown apothecia but these have a darker (brown) margin instead of the dark violet in the new species, and the ascospores are wider $[1.5-2(-2.5) \mu \mathrm{m}]$. Although the type collection of $B$. violacea is rather 


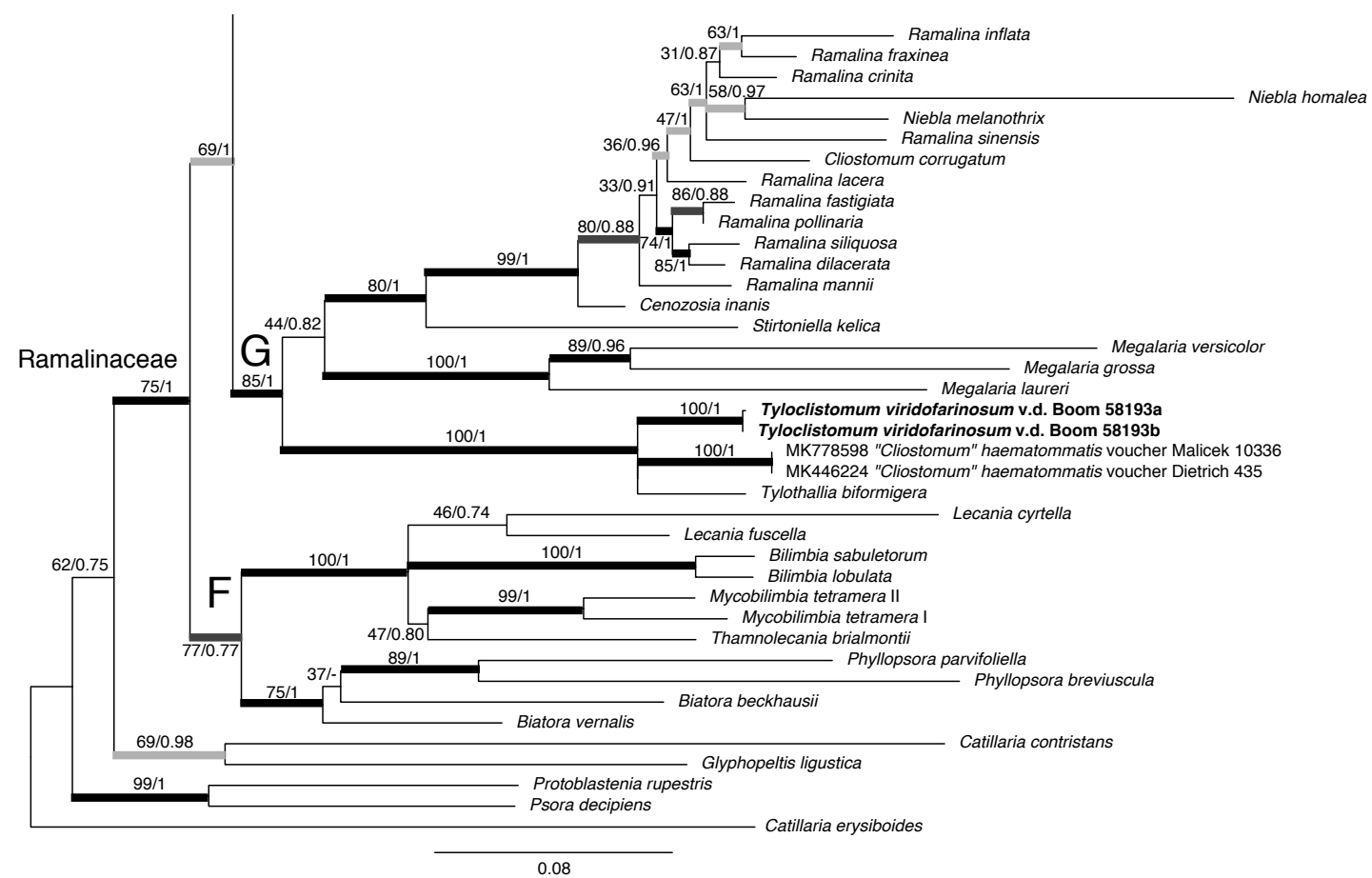

Figure 4. Continued.

large, with $>100$ apothecia, no pycnidium could be found, which is also the case in the collection from Madeira. For further main diagnostic features of similar Bacidina species, see Table 1.

Additional specimens examined. PORTUGAL. Madeira, E of Funchal, Palheiro Gardens, mixed shrubs and trees, including many mature trees, $32^{\circ} 38.58^{\prime} \mathrm{N}, 16^{\circ} 52.04^{\prime} \mathrm{W}, 520 \mathrm{~m}, 4$ April 2019, P. \& B. van den Boom 58134 (herb. van den Boom).

Tylocliostomum van den Boom \& Magain gen. nov.

Mycobank MB 834079

Diagnosis: Distinguished from Tylothallia by having Catillaria-type asci, simple paraphyses, lack of gel-coated hyphae in excipulum, and from Cliostomum by the prosoplectenchym cells in the excipulum, Catillaria-type asci, lack of pycnidia and the lack of chemical compounds.

Generic type: Tylocliostomum viridifarinosum van den Boom \& Magain.

Etymology. The new genus is named after the phylogenetic relationship with the genus Tylothallia and the similarity in habitus to Cliostomum species such as C. griffithii.

Tylocliostomum viridifarinosum van den Boom \& Magain, sp. nov.

(Fig. 3A-B)

\section{Mycobank MB 834080}

Diagnosis: Thallus, thin, continuous, farinose, granules (goniocysts) 8-20 $\mu \mathrm{m}$ diam., green, apothecia $0.15-0.4 \mathrm{~mm}$ diam., flat to convex, proper margin often visible, concolorous with or paler than disc, becoming excluded, disc white to pale cream or medium grey, sometimes with bluish grey tinge, ascospores narrow ellipsoid to bacillar, $11-15(-17) \times 2.5-3(-3.2) \mu \mathrm{m}, 1$-septate, thin-walled; no chemical compounds detected.
Type: Portugal, Madeira, NW of Funchal, road (ER228), from Ribeira Brava to São Vicente, $1.5 \mathrm{~km} \mathrm{~N}$ of Boca da Encumeada, Chão dos Louros, very big picnic area with mature trees along laurisilva, $32^{\circ} 45.62^{\prime} \mathrm{N}, 17^{\circ} 00.98^{\prime} \mathrm{W}, 825 \mathrm{~m}, 5$ April 2019, P. \& B. van den Boom 58193 (LG - holotype; LISU, herb. van den Boom - isotypes).

Description. Thallus thin, continuous, farinose, granules (goniocysts) 8-20 $\mu \mathrm{m}$ diam., bright green. Prothallus not present. Photobiont chlorophycean, cells 5-11 $\mu \mathrm{m}$ diam. Apothecia usually present, $0.15-0.4 \mathrm{~mm}$ diam., flat to slightly convex. Proper margin often visible, sometimes well developed, up to $50 \mu \mathrm{m}$ wide and present especially in young apothecia, the concolorous with or somewhat paler than disc, often becoming excluded. Disc white to pale cream, very pale yellowish, sometimes with bluish grey tinge, scattered over apothecia, or completely medium grey. Excipulum sometimes well developed and rather thick, 40-60 $\mu \mathrm{m}$ wide, with small prosoplectenchym cells filled with fine granular crystals (studied in polarised light), hyaline. Hymenium 45-60 $\mu \mathrm{m}$ high, hyaline. Epithecium pale greyish brown to very pale brown or pale bluish brown, filled with fine crystals (studied in polarised light). Hypothecium hyaline, $50 \mu \mathrm{m}$ high. Paraphyses simple, usually septate, $1.2-1.8 \mu \mathrm{m}$ wide, apices sometimes somewhat widened, 2.5-4 $\mu \mathrm{m}$ diam., tips hyaline to sometimes pale bluish brownish. Asci cylindrical-clavate to clavate, 8-spored, Catillaria-type, sometimes with relatively small ocular chamber, $23-35 \times 12-15 \mu \mathrm{m}$. Ascospores narrow ellipsoid to bacillar, 11-15(-17) × 2.5-3(-3.2) $\mu \mathrm{m}, 1$-septate, thin-walled, often with two oil droplets in one cell. Pycnidia not detected.

No chemical compounds detected.

Etymology. The epithet refers to the habitus of the thallus, which is farinose and clearly green. 
Habitat and distribution. This new species is abundantly present in the type locality, growing on twigs of Erica shrubs. Cliomegalaria symmictoides and Endohyalina ericina, whose presence is revealed by many or few apothecia, respectively, share this habitat.

Notes. In the field, Tylocliostomum viridifarinosum is easily mistaken for Cliomegalaria symmictoides because the apothecia are cream-coloured and slightly convex and appressed, but the thallus differs, being areolate, not farinose, with a somewhat shiny upper surface, and the ascospores are thick-walled, 1-septate and much wider $(4.5-6.5 \mu \mathrm{m})$. The habitus of the new genus somewhat resembles Cliostomum, especially if the ascomata are pale in the latter. The hyaline ascospores in Cliostomum griffithii are usually also 1-septate, but sometimes wider, reaching $3.5 \mu \mathrm{m}$ in width versus $3.2 \mu \mathrm{m}$ maximum in T. viridifarinosum. Cliostomum species have usually numerous, conspicuous black pycnidia, which seem to be absent in the new species. The relationship with the genus Tylothallia is unexpected, because T. biformigera, known from the temperate zone of the Northern Hemisphere, develops a thick rimose thallus with dark brown apothecia, on acidic rock (Smith et al. 2009).

\section{Acknowledgements}

We dedicate this paper to Professor Emmanuël Sérusiaux in honour of his many contributions to lichenology and for his valuable collaborations on joint projects. We thank Laurent Gohy for technical assistance in the lab.

\section{Supplementary electronic material}

Table S1. Specimens used in phylogenetic analyses, with species name, voucher or isolate information, and sequence GenBank numbers. Newly described taxa and newly generated sequences are bolded. Download file

\section{References}

Aptroot, A., Rodrigues, F., Schumm, F., Câmara, S. \& Gabriel, R. 2010. Lista dos líquenes e fungos liquenícolas (Fungi). In: Borges, P. A. V., Costa, A. C., Cunha, R., Gabriel, R., Gonçalves, V., Martins, A. F., Melo, I., Parente, P. M., Raposeiro, P., Rodrigues, P., Santos, R. S., Silva, L., Vieira, P. \& Vieira, V. Listagem dos Organismos Terrestres e Marinhos dos Açores, pp. 27-51. Princípia, Cascais.

Carvalho, P., Figueira, R. \& Jones, M. P. 2008. Os líquenes e fungos liquenícolas (Fungi) dos arquipélagos da Madeira e das Selvagens. In: Borges, P. A. V., Abreu, C., Aguiar, A. M. F., Carvalho, P., Jardim, R., Melo, I., Oliveira, P., Sérgio, C., Serrano, A. R. M. \& Vieira, P. Listagem dos Fungos, Flora e Fauna Terrestres dos Arquipélagos da Maderia e Selvagens, pp. 95-122. Secretaria Regional do Ambiente e dos Recursos Naturais do Governo Regional da Madeira, Madeira.

Cubero, O. F., Crespo, A. N. A., Fatehi, J. \& Bridge, P. D. 1999. DNA extraction and PCR amplification method suitable for fresh, herbarium-stored, lichenized, and other fungi. Plant Systematics and Evolution 216: 243-249.

Czarnota, P. \& Guzow-Krzemińska, B. 2012. ITS rDNA data confirm a delimitation of Bacidina arnoldiana and B. sulphurella and support a description of a new species within the genus Bacidina. The Lichenologist 44: 743-755.
Czarnota, P. \& Guzow-Krzemińska, B. 2018. Bacidina mendax sp. nov., a new widespread species in Central Europe, together with a new combination within the genus Bacidina. The Lichenologist 50: 43-57.

Gardes, M. \& Bruns, T. D. 1993. ITS primers with enhanced specificity for basidiomycetes-application to the identification of mycorrhizae and rusts. Molecular Ecology 2: 113-118.

Guzow-Krzemińska, B., Sérusiaux, E., van den Boom, P. P. G., Brand, A. M., Launis, A., Łubek, A. \& Kukwa, M. 2019. Understanding the evolution of phenotypical characters in the Micarea prasina group (Pilocarpaceae) and descriptions of six new species within the group. MycoKeys 57: 1-30.

Hawksworth, D. L., Earland-Bennett, P. M. \& Coppins, B. J. 2006. Lichenophoma haematommatis, a previously overlooked European sorediate species of Cliostomum (Lecanorales, Ramalinaceae). Herzogia 19: 5-10.

Hofstetter, V., Miadlikowska, J., Kauff, F. \& Lutzoni, F. 2007. Phylogenetic comparison of protein-coding versus ribosomal RNA-coding sequence data: a case study of the Lecanoromycetes (Ascomycota). Molecular Phylogenetics and Evolution 44: 412-426.

Huelsenbeck, J. P. \& Ronquist, F. 2001. MRBAYES: Bayesian inference of phylogenetic trees. Bioinformatics 17: 754-755.

Katoh, K. \& Standley, D. M. 2013. MAFFT multiple sequence alignment software version 7: improvements in performance and usability. Molecular Biology and Evolution 30: 772-780.

Kistenich, S., Timdal, E., Bendiksby, M. \& Ekman, S. 2018. Molecular systematics and character evolution in the lichen family Ramalinaceae (Ascomycota: Lecanorales). Taxon 67: 871-904.

Lanfear, R., Frandsen, P. B., Wright, A. M., Senfeld, T. \& Calcott, B. 2016. PartitionFinder 2: new methods for selecting partitioned models of evolution for molecular and morphological phylogenetic analyses. Molecular Biology and Evolution 34: 772-773.

Maddison, W. \& Maddison, D. 2016. Mesquite. A modular system for evolutionary analysis. Version 3.11. www.mesquiteproject.org

Magain, N. 2018. PLexus, a PERL package to handle DNA matrices. Available from the author. https://github.com/NicolasMagain/ PLexus

Mark, K., Cornejo, C., Keller, C., Flück, D. \& Scheidegger, C. 2016. Barcoding lichen-forming fungi using 454 pyrosequencing is challenged by artifactual and biological sequence variation. Genome 59: 685-704.

Meyer, B. \& Printzen, C. 2000. Proposal for a standardized nomenclature and characterization of insoluble lichen pigments. The Lichenologist 32: $571-583$.

Miller, M. A., Pfeiffer, W. \& Schwartz, T. 2010. Creating the CIPRES Science Gateway for inference of large phylogenetic trees. In 2010 gateway computing environments workshop (GCE): 1-8.

Orange, A., James, P. W. \& White, F. J. 2001. Microchemical methods for the identification of lichens. British Lichen Society. British Lichen Society.

Pitard, J. \& Harmand, J. 1911. Contribution à l'étude des lichens des îles Canaries. Mémoires de la Société botanique de France 2: $1-69$.

Rambaut, A. \& Drummond, A. J. 2007. Tracer v1. 5.0. Available online at: http://tree.bio.ed.ac.uk/software/figtree

Smith, C. W., Aptroot, A., Coppins, B. J., Fletcher, A., Gilbert, O. L., James, P. W. \& Wolseley, P. A. (eds) 2009. The Lichens of Great Britain and Ireland. The British Lichen Society, Department of Botany, The Natural History Museum, London.

Stamatakis, A. 2006. RAxML-VI-HPC: maximum likelihood-based phylogenetic analyses with thousands of taxa and mixed models. Bioinformatics 22: 2688-2690.

Stamatakis, A., Hoover, P. \& Rougemont, J. 2008. A rapid bootstrap algorithm for the RAxML web servers. Systematic Biology 57: 758-771.

Stiller, J. W. \& Hall, B. D. 1997. The origin of red algae: implications for plastid evolution. Proceeding of the National Academy of Science of the United States of America 94: 4520-4525. 
Van den Boom, P. P. G. 2015a. Further new or interesting lichens and lichenicolous fungi from Madeira with notes on the genus Gyalidea in Macaronesia. Folia Cryptogamica Estonica 52: 73-79.

Van den Boom, P. P. G. 2015b. Notes on the genus Anisomeridium (lichenized Ascomycotina) from Madeira and the Azores (Macaronesia). Phytotaxa 205: 65-70.

Van den Boom, P. P. G. 2016. Lichens and lichenicolous fungi of the Azores (Portugal), collected on São Miguel and Terceira with the descriptions of seven new species. Acta Botanica Hungarica 58: 199-222.

Van den Boom, P. \& Ertz, D. 2014. A new species of Micarea (Pilocarpaceae) from Madeira growing on Usnea. The Lichenologist 46: 295-301.

Van den Boom, P. P. G. \& Alvarado, P. 2019. Lichens and lichenicolous fungi of Faial, (Azores, Portugal), with the descriptions of three new species. Herzogia 32: 421-437.
Wheeler, D. L., Barrett, T., Benson, D. A., Bryant, S. H., Canese, K., Chetvernin, V., Church, D. M., DiCuccio, M., Edgar, R., Federhen, S., Geer, L. Y., Kapustin, Y., Khovayko, O., Landsman, D., Lipman, D. J., Madden, T. L., Maglott, D. R., Ostell, J., Miller, V., Pruitt, K. D., Schuler, G. D., Sequeira, E., Sherry, S. T., Sirotkin, K., Souvorov, A., Starchenko, G., Tatusov, R. L., Tatusova, T. A., Wagner, L. \& Yaschenko, E. 2007. Database resources of the national center for biotechnology information. Nucleic Acids Research 35: D5-D12.

White, T. J., Bruns, T., Lee, S. \& Taylor, J. 1990. Amplification and direct sequencing of fungal ribosomal RNA genes for phylogenetics. PCR Protocols: A Guide to Methods and Applications 18: $315-322$.

Zoller, S., Scheidegger, C. \& Sperisen, C. 1999. PCR primers for the amplification of mitochondrial small subunit ribosomal DNA of lichenforming ascomycetes. The Lichenologist 31: 511-516. 